УДК $811: 81 ' 276.6$

\author{
H. Pochtaruk \\ O. Zaitseva \\ E. Vorobiova
}

\title{
SEMANTIC FEATURES OF THE HIGH-FREQUENCY NOUN SYSTEM IN THE ENGLISH TEXT CORPUS «ACOUSTICS AND ULTRASONIC TECHNOLOGY»
}

The presented paper reports the results of the comparative analysis obtained in the process of studying the interaction between the dictionary definitions of the noun system fixed in Webster's and their lexical-semantic variants, which occur in the real text corpora of the areas referred to the scientific and technical discourse. The basic methods applied in the process of experimental study are comparative and contextual analyses.

Key words: concept, dictionary entry, frequency of usage, meaning, semantic structure, word token.

DOI 10.34079/2226-3055-2019-12-20-255-262

Scientific approaches to the study of linguistics, and in particular - the sections dealing with semantics have recently undergone a significant transformation. To verify this one should analyze the basic directions existing at the end of the last century and then compare them with the scientific themes of modern linguistic research. The one (research) carried out at the end of the last century, considered the interaction of paradigmatic and syntagmatic units within the framework of the commonly accepted theory of language as a system of signs. We should distinguish the following works among them: a study on indication of the various word sets connected by a common structural-semantic characteristic, for example, such as derivative nodes [7]; the work by L. D. Tarasova [10], in which, in addition to describing the system of lexical-semantic variants and their links, the semantic structures of language and speech are compared; the one by A. A. Loshakova [6], which describes the dependence of lexical-semantic variants of the verb on its syntactic position in text. The analysis of the linguistic status of a lexical-semantic variant can be found in the work by L. S. Shestopalova [12]. It should be noted that the overwhelming majority of studies were carried out both on the basis of text corpora and lexicographical resources in order to determine the interaction of units of language and speech.

At the present stage of linguistics development, semantics is considered mainly from the theoretical point of view of cognitive science, i.e. the semantic characteristics of language units are described in the aspect of mental processes. Numerous works in this field are devoted to almost all types of linguistic objects - from prepositions [5] to semantic models of whole sentences $[3 ; 4 ; 11]$.

But a sharp opposition of two approaches - structural and cognitive - to the problem of studying the language object semantics is not characteristic for modern researchers. They prefer to use an integrated approach to describe semantic models. This is especially true for such a multi-aspect linguistic object as a sentence. For example, the researchers E. V. Fomicheva, E. V. Lobanova [3; 4; 11] apply several approaches in semantic analysis of the sentence, since, according to E. V. Fomicheva «... the contents of the sentence includes not only the characteristics of extra-linguistic reality, but also their reflection in the human 
mind as conceptual structures, communicative positions of the participants of communication, features of the language itself» [11, p. 136].

However the authors of the given article are most interested in the description of dictionary definition analysis of polysemous words and interaction of the semantic structures of language and speech. From this point of view the work by S. A. Pesina [8], which considers the nature of the «language-speech» dichotomy by identifying the nature and cognitive mechanisms of lexical polysemy formation as well as the one by V. M. Klevtsova [2] which investigates the problem of indication of an integral feature that combines all lexical-semantic variants included in the semantic word structure in order to conserve an original cognitive image are the most valuable and informative.

However, it seems that the problem which regards to the interaction of the language and speech units is still far from exhausted and requires the further study. This concerns first of all such discourse objects as text corpora of scientific and technical fields of knowledge. The presence of a very small number of results reflecting the study of the semantic structure implementation of words in the texts of scientific and technical discourse can be explained by the fact that for the linguists, whose scientific interests lie commonly in the humanitarian field, their research is significantly obstructed by the lack of knowledge of technical specialties. However, for those who teach English at higher technical school institutions a great deal of practical experience as well as the opportunity to communicate with specialists in any scientific technical field allows performing the necessary contextual research quite correctly.

In the given article the texts of the technical specialty "Acoustics and Ultrasonic Technology» (AUST) taken from the corresponding US scientific journals - The Journal of Acoustic Society of America, IEEE International Conference on Acoustics, Speech, and Signal Processing - are used as a material of the study. The total size of the text corpus is 200 thousand word tokens.

The goal of the article is to describe the semantic characteristics of one of the most high-frequency nouns that functions in the "Acoustics and Ultrasonic Technology» text corpus - system, with their further comparison with the similar characteristics of the noun system occuring in another text corpus - «Automation of heat and power processes» (AHPP). The AHPP analysis was carried out earlier on the material of the English text corpus with the size of 200 thousand word tokens [9]. As one can see these two text corpora belong to completely different scientific areas. The authors suppose that such a study will make it possible to draw conclusions that can be correct for any (perhaps with some exceptions) technical field.

The semantic characteristic description of the noun system comes down to the comparison of the dictionary entry definitions of the word system fixed in one of the normative dictionaries, with lexical-semantic variants (LSVs) of this word found in the text corpus AUST by means of contextual analysis. Thus, the analysis permits to indicate the extent, to which the semantic structure of the word system reflected in the system of language is implemented in speech, i.e. in texts. In addition, as already mentioned the results of the analysis are compared with the data obtained in studying the texts of the specialty AHPP.

After careful consideration of the normative dictionaries, Webster's Third New International Dictionary [13] has been chosen as the most competent because, on the authors' opinion, it presents the semantic structure of the noun system most fully.

The statistical analysis has shown that the word system is one of the most frequently used nouns of the specialty AUST $(F=410)$. In the specialty AHPP texts the value of its occurrence is much higher $(\mathrm{F}=1459)$, i.e. more than three times. It is known that quantitative 
characteristics play a decisive role not only in referring a word to a particular type of discourse [1] but also in creating the certain groups of text corpora combining specialties that are common in their scientific and technical subjects. Therefore, the fact of significant difference in the quantitative values in the word system occurrence in the text corpus under consideration and the one AHPP confirms that the specialties AUST and AHPP have very few common theoretical and practical points.

The comparative analysis of the dictionary entry definitions of the noun system (which reflects the semantic structure of the word) fixed in the system of language -Webster's dictionary - and the lexical-semantic variants of this word implemented in the text AUST will be presented as follows. First, the list of dictionary definitions will be reviewed in the order taken into account in Webster's dictionary. Then, all lexical-semantic variants, which implement the semantic structure of the word system in the AUST text corpus, will be given in full. They will be confirmed by the corresponding examples. And finally the comparative analysis of language and speech units will be carried out while the LSVs used in the AUST texts will be compared with the same lexical-semantic variants that are encountered in the AHPP text corpus.

So, the noun system entry contains the following 10 dictionary definitions:

1) a unity or organic whole; 2) the world of the universe; 3) the body is considered as a functioning organism; 4) a set of facts, principles, rules, etc. For the various parts; 5) a method or plan of classification; 6) a regular orderly way of doing something; 7) a number of body functions; 8) an arrangement of rocks, showing you how it was formed during a given geological period; 9) a group of transportation lines under a common owner; 10) in chemistry, a group of substances in or approaching equilibrium.

The list of lexical-semantic variants reflecting the semantic structure of the noun system in the AUST text corpus:

a) installation, e.g. Additional characteristics of synthetic aperture system and a further comparison with non-synthetic aperture sonar systems;

b) device, e.g. Once the device units have been measured, for instance, loudspeaker system development can be proceeded by computer aided design of crossovers without resource to physical construction;

c) communications, e.g. The main objective of the research was to assess the compatibilities of adaptive arrays for communication systems in real environment;

d) set, e.g. This property of self-cohering arrays alters the design and manufacturing problems of large arrays. It may prove to be the factor, which eventually permits the construction of huge systems;

e) apparatus, e.g. The echosounds system is useful in studying the properties of the atmospheric structure;

f) computer, e.g. However, experimental data obtained from tests performed on an experimental analog processor indicate that the variance expression-properly integrated - correctly characterized the performance of the analog system as well;

g) coordinate system, e.g. The Graph addition Theorem is used to transform the total field into the coordinate system of each cylinder;

h) method, way, e.g. The problem of dynamic range in the impulse measuring system is highlighted by considering the spectral equivalent of the short pulse, shown in Fig.5;

i) command of the fleet and Naval Forces, e.g. Support for the project came from the Navel Sea Systems Command, the Navel Material Command and the National Science Foundation.

The comparative analysis of Webster's [12] dictionary definitions and lexical-semantic variants found in the AUST text corpus shows the following: 
- dictionary definition 1) «a set or arrangement of things so related or connected as to form a unity or organic whole», which is obviously etymologically the original meaning of the noun system, does exist in the AUST texts but is only at the fourth place as regard to the frequency usage and is implemented by LSV d).

In the AHPP text corpus this definition is also described although the LSV takes only the eighth place as regard to its frequency of usage, e.g. First, well review the basic concepts behind feedwater control as practiced by the system designers-architect / engineers.

- dictionary definition 2) «the world of the universe». Between dictionary definitions 1) and 2) one can find a certain semantic coincidence. Some dictionaries even note the absence of this element in the noun system dictionary entry since definition 1) completely replaces it. In the text corpus under study, an AUST lexical-semantic variant corresponding to this definition is absent, just as in the AHPP text body;

- dictionary definition 3) «the body is considered as a functioning organism». Here one can also note its definite semantic coincidence with definition 1). In the AUST text corpus this dictionary definition corresponds to lexical-semantic variants a), b), e), f). As for the LTVs of the AHPP text corpus the results show that in AHPP this definition is used in five lexical-semantic variants - a), b), d), g), h) which implies a greater variety of meanings, we give at least two of them, e.g. Clearly, a knowledge of these response characteristics is essential to the system designer; b) What should the hardware and software packages that make up the system contain.

Thus, all three presented definitions have a common semantic (conceptual) basis and can be reduced to one, namely, a group of related parts working together. Lexical-semantic variants that correspond to these three definitions in the text corpora can easily be replaced with each other or summarized into one invariant that combines the concepts of definitions 1), 2), 3). However, in practice, all phrases, in which the mentioned LSVs were observed, correspond to certain lexical cliches included in the terminological system of the specialty «Acoustics and Ultrasonic Technology». They (clichés) are exactly related to each of these three dictionary definitions, which requires their (definitions) obligatory presence in the semantic structure of the noun system. A similar picture is observed with these LSVs in the text body «Automation of heat and power processes»;

- and again a partial coincidence can be observed in the concepts of definition 4) «a set of facts, principles, rules, etc. classified or arranged in a regular, orderly form so as to show a logical plan linking the various parts» and definitions 1). However, some differences of sense character in the contents aspect give reason to consider the lexical-semantic variants c), d), related to definition 4) as independent elements of the semantic structure of the word system. In addition to the examples already given above for c), d) we are going to present another example - «This system of equations will have a non-trivial solution only if the determinant of the coefficient is zero». The lexical-semantic variants relating to definition 4) and prove its originality and difference from definition 1) were also found in the AHPP text corpus. However, if in the texts AUST there are only two such kind of LSVs then in the AHPP texts there are five of them (we are giving at least two), e.g. Designed to meet the zero-discharge commitment, this system includes a 156-gpm vaporcompression brine concentrator and a 1200-gpm reverse-osmosis unit providing $95 \%$ overall recovery of water;

- dictionary definitions 5) «a method or plan of classification» and 6) «a regular orderly way of doing something» fixed in Webster's have almost identical semantic meanings, and in the AUST texts occur as LSVs g) and h), respectively. However, these lexical-semantic variants are not observed in the specialty AHPP texts; 
- dictionary definitions 7), 8), 9), 10) provide for the regularities of lexical compatibility that are not typical for the lexical units of the considered AUST text corpus as well as for units of the AHPP corpus being compared with AUST. Therefore, lexical-semantic variants that describe these definitions were not found in the analyzed corpora. (In any case, within the limits of those 200 thousand word tokens that were subjected to the contextual analysis in this article, and 200 thousand word tokens in the specialty AHPP).

So, the analysis of the dictionary definitions of the high-frequency noun system, the contextual analysis of the text corpus «Acoustics and Ultrasound Technology» and the comparative analysis of the results of text research of AUST and «Automation of heat and power processes» have shown the following.

1. The high-frequency noun system occurs in the AUST texts with frequency 410 word tokens. In the AHPP specialty text corpus, which is compared to the AUST corpus, and which has no common problems with AUST according to its scientific subject, this value is much higher $-1,459$ word tokens.

2. On the basis of results of the high-frequency noun system analysis the thesis about the sharp reduction of the semantic structure of word, which is distinctive for texts of scientific and technical discourse, put forward by many linguists-theorists, is not confirmed. In the text corpora of the technical specialties AUST and AHPP the semantic structure of the word system is reflected quite extensively although all definitions presented in the language system are not covered by the LSVs.

3. Six of ten definitions of the word system fixed in Webster's normative dictionary are implemented in the AUST text corpus: 1) a set or arrangement of things so related or connected as to form a unity or organic whole; 2) the world of the universe; 3) the body considered as a functioning organism; 4) a set of facts, principles, rules, etc. classified or arranged in a regular, orderly form so as to show a logical plan linking the various parts; 5) a method or plan of classification; 6) a regular orderly way of doing something. The remaining four definitions have the notions that are not characteristic for technical areas of knowledge and accordingly do not occur in the texts. A similar position can be seen in the AHPP texts.

4. The six definitions mentioned are implemented in the AUST texts with the help of eight LSVs, one of which - d) set - is registered when describing two definitions 1) «a set or arrangement of things so related or connected as to form a unity or organic whole» and 4) «a set of facts, principles, rules, etc. classified or arranged in a regular, orderly form so as to show a logical plan linking the various parts». The largest number of LSVs (four) describes definition 3) «the body is considered as a functioning organism»a) installation; b) device; e) apparatus; f) computer.

5. One of the LSVs - i) «command of the fleet and Naval Forces» - is not represented in the definition entry of Webster's dictionary though it is used in the text corpus, which makes appearing a new semantic element in the dictionary definition of the noun system that will reflect this LSV quite possible. The semantic structure of the word system implemented in the AHPP texts is characterized by an even greater number of lexical-semantic variants that are not taken into account in the dictionary definition entry in Webster's dictionary - station, substation; electric circuit, network; company, enterprise; structure.

6. The presented results of the comparative analysis have shown the hierarchical discrepancies between dictionary definitions and LSVs, in which they are implemented in the texts. This is especially evident in the texts of the area AHPP.

The analysis showed that the comparison of only two text corpora of the technical areas AUST and AHPP left some statistically unclear and unresolved issues. Therefore, for the further comparative analysis the authors are going to introduce one more - the third - text 
corpus, which is not thematically connected with the technical areas "Acoustics and Ultrasonic Technology» and «Automation of Heat and Power Processes».

\section{References}

1. Алексеев П. М. Статистическая лексикография (типология, составление и применение частотных словарей) / П. М. Алексеев. - Ленинград : ЛГПИ, 1975. - 120 с. ; Alekseev P. M. Statisticheskaya leksikografiya (tipologiya, sostavlenie i primenenie chastotnykh slovarey) / P. M. Alekseev. - Leningrad : LGPI, 1975. - 120 s.

2. Клевцова В. М. Семантическая структура основных лексических единиц со значением «жадность» в современном английском языке [Электронный ресурс] / В. М. Клевцова // Динамика изследвания : матер. за 4-а Международна научна практична конференция. - София : Бял ГРАД-БГ ООД, 2008. - Т. 15 : Филологические науки. - C. 5-8. http://www.rusnauka.com/15_DNI_2008/Philologia/33575.doc.htm ; Klevtsova V. M. Semanticheskaya struktura osnovnykh leksicheskikh edinits so znacheniem «zhadnost» V sovremennom angliyskom yazyke [Elektronnyy resurs] / V. M. Klevtsova // Dinamika izsledvaniya : mater. za 4-a Mezhdunarodna nauchna praktichna konferentsiya. - Sofiya : Byal GRAD-BG OOD, 2008. - T. 15 : Filologicheskie nauki. - S. 5-8. - Rezhim dostupa : http://www.rusnauka.com/15_DNI_2008/Philologia/33575.doc.htm

3. Лобанова Е. В. Моделирование семантической структуры средств выражения побудительности в английском языке, выражающих «Запрет», в свете когнитивноонтологического подхода / Е.В.Лобанова // Вестник Челябинского педагогического университет. - 2011. - № 3. - C. 261-270; Lobanova Ye. V. Modelirovanie semanticheskoy struktury sredstv vyrazheniya pobuditelnosti $\mathrm{v}$ angliyskom yazyke, vyrazhayushchikh «Zapret», v svete kognitivno-ontologicheskogo podkhoda / Ye. V. Lobanova // Vestnik Chelyabinskogo pedagogicheskogo universitet. - 2011. - № 3. S. 261-270.

4. Лобанова Е. В. Средства выражения побудительности в английском языке : когнитивно-онтологический подход : автореф. дис. ... канд. филол. наук : спец. 10.02.04 / Елена Владимировна Лобанова ; Поволж. гос. соц.-гуманитар. акад. - Самара, 2011. 23 c. ; Lobanova Ye. V. Sredstva vyrazheniya pobuditelnosti v angliyskom yazyke : kognitivno-ontologicheskiy podkhod: avtoref. dis. ... kand. filol. nauk: spets. 10.02.04 / Yelena Vladimirovna Lobanova ; Povolzh. gos. sots.-gumanitar. akad. - Samara, 2011. $23 \mathrm{~s}$.

5. Логинова Е. Г. Концептуальное соотношение пространства и времени в семантике английских предложных сочетаний : дис. ... канд. филол. наук : спец. 10.02.04 / Елена Георгиевна Логинова ; Моск. ордена Дружбы народов гос. лингв. ун-т. - Москва, 2004. - 251 с. ; Loginova Ye. G. Kontseptualnoe sootnoshenie prostranstva i vremeni $\mathrm{v}$ semantike angliyskikh predlozhnykh sochetaniy : dis. ... kand. filol. nauk : spets. 10.02.04 / Yelena Georgievna Loginova ; Mosk. ordena Druzhby narodov gos. lingv. un-t. Moskva, 2004. - $251 \mathrm{c}$.

6. Лошакова А. А. Исследование семантической структуры и сочетаемости групп глаголов, выражающих понятие «поддерживать» (на материале современного английского языка) : дис. .... канд.. филол.. наук : спец. 10.02.04 / Алла Алексеевна Лошакова ; Моск. гос. пед. ин-т им. В. И. Ленина. - Москва, 1983. - 231 с. ; Loshakova A. A. Issledovanie semanticheskoy struktury i sochetaemosti grupp glagolov, vyrazhayushchikh ponyatie "podderzhivat» (na materiale sovremennogo angliyskogo yazyka) : dis. .... kand.. filol.. nauk : spets. 10.02.04 / Alla Alekseevna Loshakova; Mosk. gos. ped. in-t im. V. I. Lenina. - Moskva, 1983. - $231 \mathrm{~s}$. 
7. Мельник С. К. Семантическая структура отглагольного словообразовательного гнезда в современном английском языке : автореф. дис. ... канд. филол. наук : спец. 10.02.04 / Светлана Константиновна Мельник; Моск. гос. пед ин-т ин. языков им. М. Тореза. - Москва, 1984. - 21 с. ; Melnik S. K. Semanticheskaya struktura otglagolnogo slovoobrazovatelnogo gnezda v sovremennom angliyskom yazyke : avtoref. dis. ... kand. filol. nauk : spets. 10.02.04 / Svetlana Konstantinovna Melnik ; Mosk. gos. ped in-t in. yazykov im. M. Toreza. - Moskva, 1984. - $21 \mathrm{~s}$.

8. Песина С. А. Исследование семантической структуры слова на основе прототипической семантики : на материале английских существительных : дис. ... докт. філол. наук : спец. 10.02.04 / Светлана Андреевна Песина; Российск. гос. пед. ун-т им. А. И. Герцена. - Санкт-Петербург, 2005. - 384 с. ; Pesina S. A. Issledovanie semanticheskoy struktury slova na osnove prototipicheskoy semantiki: na materiale angliyskikh sushchestvitelnykh: dis. ... dokt. filol. nauk: spets. 10.02.04 / Svetlana Andreevna Pesina ; Rossiysk. gos. ped. un-t im. A. I. Gertsena. - Sankt-Peterburg, 2005. $384 \mathrm{~s}$.

9. Почтарук Г. Я. Реализации семантической структуры английского существительного system в текстовом корпусе «Автоматизация теплоэнергетических процессов» / Г. Я. Почтарук, О. Ю. Зайцева, А. А. Хуторная // Одеський лінгвістичний вісник. - 2017. - Вип. 9 (1). - С. 207-210 ; Pochtaruk H. Ya. Realyzatsyy semantycheskoi strukturb anhlyiskoho sushchestvytelnoho system v tekstovom korpuse «Avtomatyzatsyia teploэnerhetycheskykh protsessov» / H. Ya. Pochtaruk, O. Yu. Zaitseva, A. A. Khutornaia // Odeskyi linhvistychnyi visnyk. - 2017. - Vyp. 9 (1). - S. 207-210.

10. Тарасова Л. Д. О языковом статусе лексико-семантических вариантов и их соотношение в семантической структуре слова / Л. Д. Тарасова // Семантика слова и предложения в английском языке: межвуз. сб. науч. тр. - Ленинград: ЛГПИ им. А. И. Герцена, 1980. - С. 50-63; Tarasova L. D. O yazykovom statuse leksikosemanticheskikh variantov i ikh sootnoshenie $\mathrm{v}$ semanticheskoy strukture slova / L. D. Tarasova // Semantika slova i predlozheniya v angliyskom yazyke: mezhvuz. sb. nauch. tr. - Leningrad : LGPI im. A. I. Gertsena, 1980. - S. 50-63.

11. Фомичева Е. В. Моделирование семантической структуры императивных предложений в английском языке / Е. В. Фомичева // Вестник Челябинского государственного университета. - 2009. - № 34. - С. 136-140 ; Fomicheva Ye. V. Modelirovanie semanticheskoy struktury imperativnykh predlozheniy $\mathrm{v}$ angliyskom yazyke / Ye. V. Fomicheva // Vestnik Chelyabinskogo gosudarstvennogo universiteta. - 2009. № 34. - S. 136-140.

12. Шестопалова Л. С. Соотношение и ранжирование лексических значений в семантической структуре слова в современном английском языке : автореф. дис. ... канд. филол. наук : спец. 10.02.04 / Людмила Семеновна Шестопалова; Ленингр. гос. пед. ин-т им. А. И. Герцена. - Ленинград, 1980. - 23 с. ; Shestopalova L. S. Sootnoshenie i ranzhirovanie leksicheskikh znacheniy v semanticheskoy strukture slova $\mathrm{v}$ sovremennom angliyskom yazyke: avtoref. dis. ... kand. filol. nauk: spets. 10.02.04 / Lyudmila Semenovna Shestopalova ; Leningr. gos. ped. in-t im. A. I. Gertsena. - Leningrad, 1980. $-23 \mathrm{~s}$.

13. Webster's Third New International Dictionary. - Springfield, Mass. : Merriam Webster, 2002. - $2662 \mathrm{p}$.

Submitted April 29th, 2019. 


\section{Г. Я. Почтарук \\ О. Ю. Зайцева \\ К. В. Воробйова \\ СЕМАНТИЧНІ ОСОБЛИВОСТІ ВИСОКОЧАСТОТНОГО ІМЕННИКА SYSТЕМ В АНГЛІЙСЬКОМУ ТЕКСТОВОМУ КОРПУСІ «АКУСТИКА ТА УЛЬТРАЗВУКОВА ТЕХНІКА»}

Проблема взаємодї й взаємного впливу одиниць системи мови та мовлення посідає одне з найважливіших місцьв в лінгвістиці. Ця стаття описує спробу дослідження такого роду взаємодії. Джерелом системи одиниць мови є словник Webster's - найбільш компетентний нормативний пояснювальний словник. У свою чергу джерелом мовних одиниць $є$ корпус технічного тексту «Акустика $i$ ультразвукова техніка», заснований на наукових статтях, щзо відповідають иій галузі знань. Розмір текстового корпусу - 200 тисяч слововживань. За об'єкт експерименту береться найбільш часто використовуваний в текстах "Акустика $і$ ультразвукова техніка» іменник system. Основна мета полягає в проведенні порівняльного аналізу, щуоб з'ясувати, у якій мірі словникові дефініції іменника system впроваджено в технічний текстовий корпус «Акустика $і$ ультразвукова техніка». 3 метою отримання результатів, які можуть бути коректними для будь-якої (можливо, з деякими винятками) технічної галузі, виконується інший вид порівняння семантичні характеристики іменника system, щуо використовуються в текстах «Акустика і ультразвукова техніка», порівнюються з подібними характеристиками, які функиіонують у текстах технічної галузі «Автоматизація теплоенергетичних прочесів». Хоча обидві галузі належать до технічного дискурсу, ӥхні наукові тематики абсолютно різні, щуо дозволяє отримати узагальнені результати.

Дослідження визначень словникових дефініцій іменника system, закріплених y Webster's, та лексико-семантичних варіантах, що відповідають ицим визначенням, використаним у текстових корпусах "Акустика та ультразвукова техніка» та «Автоматизація теплових та енергетичних процесів» показали, щчо: 1) теза про різке скорочення семантичної структури слів, щзо відрізняє тексти науковотехнічного дискурсу, висунутого багатьма лінгвістами-теоретиками, не підтверджується. Семантична структура слова system віддзеркалюється досить широко, хоча не всі дефініції, які зафіксовані в слові system, повністю висвітлені в досліджуваних текстах; 2) текстові корпуси демонструють явище, коли в наукових статтях иих двох галузей використовуються лексико-семантичні варіанти, які не закріплені в семантичній структурі іменника system $i$ таким чином не існують у словниковій статті. Такий тип лексико-семантичного варіанту є єдиним в текстах "Акустика $і$ ультразвукова техніка», а в "Автоматизащії теплових $і$ енергетичних процесів» зустрічаються сім таких випадків; 3) існують ієрархічні розбіжності між словниковими дефініціями та лексико-семантичними варіантами, в яких їхні (дефініцій) поняття реалізуються в текстах. Особливо ие можна спостерігати в текстах галузі «Автоматизація теплоенергетичних прочесів». Оскільки за результатами порівняльного аналізу залишилися деякі невирішені питання, i 3 урахуванням статистичної вірогідності результатів точки, подальші дослідження міститимуть третій текстовий корпус, який також тематично відрізняється від технічних галузей «Акустика та ультразвукова техніка» та «Автоматизація теплових і енергетичних процесів».

Ключові слова: лексико-семантичний варіант, словникова дефінічія, частота використання, слововживання, величина, текстовий корпус, науково-технічний дискурс, семантична структура. 